\title{
7,8-Secolignans from Schisandra neglecta and Their Anti-HIV-1 Activities
}

\author{
Xuemei Gao, ${ }^{a, b}$ Huaixue Mu, ${ }^{a}$ Ruirui Wang, ${ }^{c}$ Qiufen Hu, ${ }^{*, a}$ Liumeng Yang, ${ }^{c}$ \\ Yongtang Zheng, ${ }^{c}$ Handong Sun ${ }^{b}$ and Weilie Xiao ${ }^{*, a, b}$ \\ ${ }^{a}$ Key Laboratory of Chemistry in Ethnic Medicinal Resources, State Ethnic Affairs Commission \& \\ Ministry of Education, Yunnan University of Nationalities, Kunming 650031, P. R. China
}

${ }^{b}$ State Key Laboratory of Phytochemistry and Plant Resources in West China, Kunming Institute of Botany, Chinese Academy of Sciences, Kunming 650204, P. R. China

${ }^{c}$ Kunming Institute of Zoology, Chinese Academy of Sciences, Kunming 650223, P. R. China

\begin{abstract}
Quatro novas 7,8-secoligninas (neglectahenols A-D), juntamente com duas 7,8-secolignanas conhecidas, foram isoladas de folhas e caules de Schisandra neglecta. As estruturas foram elucidadas por métodos espectroscópicos, incluindo a técnica de RMN (ressonância magnética nuclear) em uma e duas dimensões. As atividades anti-HIV-1 (vírus da imunodeficiência humana tipo 1) das 7,8-secoligninas e dos neglectahenols também foram testadas, e todos mostraram atividades moderadas.
\end{abstract}

Four new 7,8-secolignans (neglectahenols A-D), together with two known 7,8-secolignans, were isolated from leaves and stems of Schisandra neglecta. The structures were elucidated by spectroscopic methods, including extensive one and two dimension NMR (nuclear magnetic resonance) techniques. 7,8-Secolignans and neglectahenols A-D were also tested for their anti-HIV-1 (human immunodeficiency virus type 1) activities, and all of them showed modest activities.

Keywords: Schisandra neglecta, 7,8-secolignan, anti-HIV-1 activities

\section{Introduction}

The genus Schisandra, comprising twenty three species of scandent and woody vines, is widely distributed in East Asia. ${ }^{1}$ Fruits and stems of Schisandra plants are commonly used in traditional Chinese medicine for the treatment of hepatitis, diabetes, diarrhea and cough and used as an astringent remedy. ${ }^{2}$ Phytochemically, plants of the genus Schisandra are a rich source of lignans ${ }^{3}$ and triterpenoids. ${ }^{4}$

Schisandra neglecta, one species of this genus, is a climbing plant mainly distributed in Southwest China. Previous chemical investigations of this plant led to the isolation of a number of dibenzocyclooctadiene lignans that showed anti-HIV-1 (human immunodeficiency virus type 1) and anti-HBV (hepatitis B virus) activities. ${ }^{5-7}$ In our continuous investigation of new biologically potent active compounds from the same plant, six 7,8-secolignans (1-6) were isolated, including four new ones named neglectahenols A-D (1-4). The structures of

*e-mail: huqiufena@yahoo.com.cn,xwl@mail.kib.ac.cn the new compounds 1-4 were established by means of mass spectrometry (MS) and extensive nuclear magnetic resonance (NMR) analyses data. In addition, the anti-HIV-1 activities of compounds 1-4 were evaluated. In this work, the isolation and structural elucidation as well as the anti-HIV activities of these compounds are reported.

\section{Results and Discussion}

A $70 \%$ aq. acetone extract prepared from leaves and stems of $S$. neglecta was partitioned between EtOAc and $\mathrm{H}_{2} \mathrm{O}$. The EtOAc layer was subjected repeatedly to column chromatography on silica gel, Sephadex LH-20, RP-18 and preparative HPLC (high performance liquid chromatography) to afford compounds 1-6, including four new 7,8-secolignans named neglectahenols A-D (1-4), together with two known 7,8-secolignans, marphenol B (5) ${ }^{8}$ and 7,8-secoholostylone B (6). ${ }^{9}$ The structures of compounds 1-6 are shown in Figure 1.

Compound 1 was obtained as a white amorphous powder, and the molecular formula $\mathrm{C}_{21} \mathrm{H}_{24} \mathrm{O}_{8}$ was assigned 


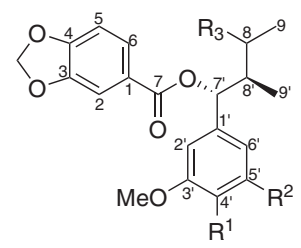

$1 \mathrm{R}^{1}=\mathrm{OMe} ; \mathrm{R}^{2}=\mathrm{OH} ; \mathrm{R}^{3}=\mathrm{OH}$ $2 \mathrm{R}^{1}=\mathrm{OH} ; \mathrm{R}^{2}=\mathrm{H} ; \mathrm{R}^{3}=\mathrm{OH}$ $5 \mathrm{R}^{1}=\mathrm{OMe} ; \mathrm{R}^{2}=\mathrm{OH} ; \mathrm{R}^{3}==\mathrm{O}$

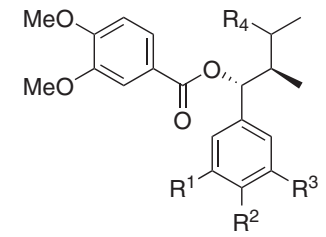

$3 \mathrm{R}^{1}=\mathrm{R}^{2}=\mathrm{R}^{3}=\mathrm{OMe} ; \mathrm{R}^{4}=\mathrm{OH}$ $4 \mathrm{R}^{1}=\mathrm{R}^{2}=\mathrm{OMe} ; \mathrm{R}^{3}=\mathrm{OH} ; \mathrm{R}^{4}=\mathrm{OH}$ $6 \mathrm{R}^{1}=\mathrm{R}^{2}=-\mathrm{OCH}_{2} \mathrm{O}-; \mathrm{R}^{3}=\mathrm{H} ; \mathrm{R}^{4}==\mathrm{O}$
Figure 1. The structures of compounds 1-6.

by HRESIMS (high resolution electrospray ionization mass spectrometry) $\mathrm{m} / \mathrm{z} 427.1372[\mathrm{M}+\mathrm{Na}]^{+}$(calcd. 427.1369). Its ${ }^{1} \mathrm{H}$ and ${ }^{13} \mathrm{C}$ NMR (Table 1) spectra showed signals of 24 hydrogens and 21 carbons, respectively, corresponding to two aromatic rings (a 3', 4'-dimethoxy5'-hydroxybenzyl and a piperonyl), one carbonyl carbon $\left(\delta_{\mathrm{C}} 165.4\right)$, two methyl groups $\left(\delta_{\mathrm{C}} 9.5,22.2\right)$, one methine carbon $\left(\delta_{\mathrm{C}} 45.1\right)$ and two oxidated methine carbons $\left(\delta_{\mathrm{C}} 65.0\right.$, 79.2) which were in accordance with the molecular formula $\mathrm{C}_{21} \mathrm{H}_{24} \mathrm{O}_{8}$. Strong absorption bands accounting for hydroxy group $\left(3475 \mathrm{~cm}^{-1}\right)$, carbonyl group $\left(1708 \mathrm{~cm}^{-1}\right)$ and aromatic groups $\left(1658,1574,1523\right.$ and $\left.1475 \mathrm{~cm}^{-1}\right)$ were also observed in its IR spectrum. The UV spectrum of 1 showed absorption maxima at 276 and $210 \mathrm{~nm}$ which confirmed the existence of the aromatic functions. In the HMBC (heteronuclear multiple-bond correlation spectroscopy) spectrum, correlations were found from H-7' $\left(\delta_{\mathrm{H}} 6.40\right)$ with C-1' $\left(\delta_{\mathrm{C}} 133.2\right), \mathrm{C}-2^{\prime}\left(\delta_{\mathrm{C}} 103.9\right)$ and C-6' $\left(\delta_{\mathrm{C}} 109.7\right)$, which positioned the 3 ',4' -dimethoxy-5'-hydroxyphenyl group at C-7'. The HMBC correlations of aromatic protons $\mathrm{H}-2$ $\left(\delta_{\mathrm{H}} 7.59\right), \mathrm{H}-6\left(\delta_{\mathrm{H}} 7.85\right)$ with C-7 $\left(\delta_{\mathrm{C}} 165.4\right)$ suggested that another aromatic ring was attached to $\mathrm{C}-7$. Moreover, the HMBC correlation of H-7' $\left(\delta_{\mathrm{H}} 6.40\right)$ with C-7 $\left(\delta_{\mathrm{C}} 165.4\right)$ indicated that $\mathrm{C}-7$ ' coupled to $\mathrm{C}-7$ through ester group. The above information implied that $\mathbf{1}$ should be a 7,8-secolignan. ${ }^{8,9}$ The spin system of $\mathrm{H}-7^{\prime} / \mathrm{H}-8^{\prime} /$ $\mathrm{H}-8 / \mathrm{H}-9$ and $\mathrm{H}-8^{1} / \mathrm{H}_{-} 9^{\prime}$ in the ${ }^{1} \mathrm{H}-{ }^{1} \mathrm{H}$ COSY (correlation spectroscopy) spectrum further confirmed the above deduction. By comparison, the ${ }^{1} \mathrm{H}$ and ${ }^{13} \mathrm{C}$ NMR spectral data of $\mathbf{1}$ are similar to those of marphenol B. ${ }^{8}$ The only difference is that the carbonyl carbon $\mathrm{C}-8\left(\delta_{\mathrm{C}} 209.5\right)$ in marphenol B was replaced by an oxidated methine carbon $\left(\delta_{\mathrm{C}} 65.0\right)$ in 1 . According to the chemical shift of $\delta_{\mathrm{C}} 65.0$ and the molecular formula of $\mathbf{1}$, a hydroxyl group should be located at C-8. Thus, the structure of $\mathbf{1}$ was established as shown and given the name as neglectahenol A.

Compounds 2-4 (neglectahenols B-D) were all obtained as white amorphous powders. By comparison of their IR, $\mathrm{UV},{ }^{1} \mathrm{H}$ and ${ }^{13} \mathrm{C}$ NMR and ROESY (rotating frame nuclear Overhauser effect spectroscopy) spectra with those of $\mathbf{1}$, compounds 2-4 were also assigned as 7,8-secolignans. The obvious chemical shift differences resulted from the substituent group variations in the aromatic rings. Compound 2 had the molecular formula $\mathrm{C}_{20} \mathrm{H}_{22} \mathrm{O}_{7}$ as revealed by its HRESIMS data $\left(\mathrm{m} / \mathrm{z}, 397.1270[\mathrm{M}+\mathrm{Na}]^{+}\right.$, calcd. 397.1263). The ${ }^{1} \mathrm{H}$ and ${ }^{13} \mathrm{C}$ NMR spectra were similar to those of $\mathbf{1}$. Analysis of HSQC, ${ }^{1} \mathrm{H}-{ }^{1} \mathrm{H}-\mathrm{COSY}$ and HMBC spectra of $\mathbf{2}$ showed chemical shift differences from the substituents at C-4' and C-5' in aromatic rings. A hydroxyl group replaced the methoxyl group at $\mathrm{C}-4$ ' and no substituent at C-5' in $\mathbf{2}$ was indicated by the downfield chemical shift of C-4' $\left(\delta_{\mathrm{C}} 148.6\right)$ and the HMBC correlations of $\mathrm{H}-5^{\prime}\left(\delta_{\mathrm{H}}\right.$ 7.11) with C-4' and C-6'. Compound 3 showed a quasimolecular ion peak at $m / z 457.1832[\mathrm{M}+\mathrm{Na}]^{+}$(calcd. 457.1838) in its HRESIMS, corresponding to the molecular formula of $\mathrm{C}_{23} \mathrm{H}_{30} \mathrm{O}_{8}$. The NMR spectrum of $\mathbf{3}$ was similar to those of $\mathbf{1}$, except for the substituents at C-3, C-4 and $\mathrm{C}-5$ ' on the two aromatic rings. A methoxyl group at C-5'

Table 1. ${ }^{13} \mathrm{C}$ NMR data of compounds 1-4 ( $\delta$ in ppm, $125 \mathrm{MHz}, \mathrm{C}_{5} \mathrm{D}_{5} \mathrm{~N}$ )

\begin{tabular}{|c|c|c|c|c|c|c|c|c|c|}
\hline Position & 1 & 2 & 3 & 4 & Position & 1 & 2 & 3 & 4 \\
\hline 1 & $125.3 \mathrm{~s}$ & $125.7 \mathrm{~s}$ & $122.5 \mathrm{~s}$ & $122.6 \mathrm{~s}$ & $4^{\prime}$ & $137.3 \mathrm{~s}$ & $148.6 \mathrm{~s}$ & $139.4 \mathrm{~s}$ & $137.4 \mathrm{~s}$ \\
\hline 2 & $109.7 \mathrm{~d}$ & $109.4 \mathrm{~d}$ & $113.5 \mathrm{~d}$ & $113.6 \mathrm{~d}$ & $5^{\prime}$ & $150.3 \mathrm{~s}$ & $116.3 \mathrm{~d}$ & $153.5 \mathrm{~s}$ & $150.7 \mathrm{~s}$ \\
\hline 3 & $148.3 \mathrm{~s}$ & $148.0 \mathrm{~s}$ & $150.6 \mathrm{~s}$ & $151.0 \mathrm{~s}$ & $6^{\prime}$ & $109.7 \mathrm{~d}$ & $121.8 \mathrm{~d}$ & $105.6 \mathrm{~d}$ & $109.9 \mathrm{~s}$ \\
\hline 4 & $152.3 \mathrm{~s}$ & $153.6 \mathrm{~s}$ & $154.6 \mathrm{~s}$ & $154.7 \mathrm{~s}$ & $7^{\prime}$ & $79.2 \mathrm{~d}$ & $79.1 \mathrm{~d}$ & $79.0 \mathrm{~d}$ & $79.2 \mathrm{~d}$ \\
\hline 5 & $108.4 \mathrm{~d}$ & $108.1 \mathrm{~d}$ & $111.3 \mathrm{~d}$ & $111.7 \mathrm{~d}$ & $8^{\prime}$ & $45.1 \mathrm{~d}$ & $45.1 \mathrm{~d}$ & $45.0 \mathrm{~d}$ & $45.5 \mathrm{~d}$ \\
\hline 6 & $125.7 \mathrm{~d}$ & $124.6 \mathrm{~d}$ & $124.5 \mathrm{~d}$ & $124.8 \mathrm{~d}$ & $9^{\prime}$ & $9.5 \mathrm{q}$ & $9.3 \mathrm{q}$ & $9.8 \mathrm{q}$ & $9.4 \mathrm{q}$ \\
\hline 7 & $165.4 \mathrm{~s}$ & $165.9 \mathrm{~s}$ & $165.5 \mathrm{~s}$ & $165.7 \mathrm{~s}$ & $\mathrm{MeO}-3$ & & & $56.0 \mathrm{q}$ & $55.8 \mathrm{q}$ \\
\hline 8 & $65.0 \mathrm{~d}$ & $65.0 \mathrm{~d}$ & $65.1 \mathrm{~d}$ & $65.0 \mathrm{~d}$ & $\mathrm{MeO}-4$ & & & $56.2 \mathrm{q}$ & $55.8 \mathrm{q}$ \\
\hline 9 & $22.2 \mathrm{q}$ & $22.4 \mathrm{q}$ & $22.6 \mathrm{q}$ & $21.8 \mathrm{q}$ & $\mathrm{MeO}-3^{\prime}$ & $55.9 \mathrm{q}$ & $55.7 \mathrm{q}$ & $55.7 \mathrm{q}$ & $55.7 \mathrm{q}$ \\
\hline $1^{\prime}$ & $133.2 \mathrm{~s}$ & $134.3 \mathrm{~s}$ & $133.7 \mathrm{~s}$ & $133.2 \mathrm{~s}$ & MeO-4' & $60.3 \mathrm{q}$ & & $60.9 \mathrm{q}$ & $60.7 \mathrm{q}$ \\
\hline $2^{\prime}$ & $103.9 \mathrm{~d}$ & $113.5 \mathrm{~d}$ & $105.6 \mathrm{~d}$ & $103.9 \mathrm{~d}$ & MeO-5' & & & $55.7 \mathrm{q}$ & \\
\hline $3^{\prime}$ & $154.0 \mathrm{~s}$ & $150.4 \mathrm{~s}$ & $153.5 \mathrm{~s}$ & $153.7 \mathrm{~s}$ & $-\mathrm{OCH}_{2} \mathrm{O}-$ & $102.5 \mathrm{t}$ & $101.9 \mathrm{t}$ & & \\
\hline
\end{tabular}


in $\mathbf{3}$ replaced the hydroxyl group at C-5' in $\mathbf{1}$ as indicated by HMBC correlations of MeO-5' $\left(\delta_{\mathrm{H}} 3.90\right)$ with C-5'. Furthermore, HMBC correlations of two methoxy groups $\left(\delta_{\mathrm{H}}\right.$ 3.68 and 3.80) with C-3 and C-4, respectively, showed their locations at $\mathrm{C}-3$ and $\mathrm{C}-4$. The molecular formula of $\mathbf{4}$ was determined as $\mathrm{C}_{22} \mathrm{H}_{28} \mathrm{O}_{8}$ from its HRESIMS at $m / z 443.1675$ $[\mathrm{M}+\mathrm{Na}]^{+}$(calcd. 443.1682). The functional groups in the IR, UV and NMR spectra were similar to those of compound $\mathbf{1}$. The obvious difference was the replacement of two methoxy groups in $\mathbf{4}$ with a methylenedioxy group in 1. HMBC correlations from the two methoxy protons $\left(\delta_{\mathrm{H}} 3.81,3.86\right)$ to C-3 and C-4 implied that two methoxy groups were attached at C-3 and C-4, respectively, instead of a methylenedioxy group attached at C-3 and C-4 in compound $\mathbf{1}$. On the basis of the above analysis, the structures of $\mathbf{2 - 4}$ were established as shown in Figure 1.

There is a hydroxyl group at C-8 in compounds 1-4 while two known compounds (marphenol $\mathrm{B}^{8}$ and 7,8-secoholostylone $\mathrm{B}^{9}$ ) have a keto-carbonyl at C-8. Therefore, there are three stereogenic centers at the side chain in compounds 1-4 instead of two stereogenic centers at this side chain in two known compounds. ${ }^{89}$ Since the coupling constants $\left(\mathrm{H}^{-} 7^{\prime}\right.$ and $\left.\mathrm{H}-8^{\prime}, J 10.3 \mathrm{~Hz}\right)$ and ROESY correlations (Figure 2) of $\mathbf{1}$ were similar to those of marphenol $\mathrm{B}^{8}$ and 7,8-secoholostylone $\mathrm{B},{ }^{9}$ in which absolute configuration was unambiguously established by CD (circular dichroism) and ROESY experiments, the relative configurations at C-7' and C-8' of 1-4 should be the same as those of marphenol $\mathrm{B}^{8}$ and 7,8-secoholostylone B. ${ }^{9}$ It was not possible to determine the relative configuration at $\mathrm{C}-8$ on the basis of coupling constants and ROESY spectra since the $\mathrm{C}-\mathrm{C}$ bonds can rotate randomly. A Mosher analysis could be useful to establish the absolute configuration at C-8. However, after carrying out the bioassays, no enough amounts of compounds remained for derivatization.

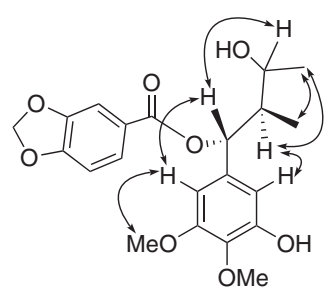

Figure 2. Key correlations ROESY( $ح)$ of 1.

Since certain of 7,8-secolignans from Schisandra genus species exhibit potential anti-HIV activities, ${ }^{8}$ the new compounds 1-4 were tested for their potencies in preventing the cytopathic effects of HIV-1 in C8166 cells. Cytotoxicity was measured in parallel with the determination of antiviral activity, using azidothymidine (AZT) as a positive control. ${ }^{10}$
The results are shown in Table 2, compounds 1-4 showed therapeutic index (TI) values of 58.65, 26.36, 23.71 and 25.85 , respectively. The TI values of all compounds are higher than these of reported 7,8-secolignans, marphenol A, marphenol B and 7,8-secoholostylone B. ${ }^{8}$ The results indicated that the reduction of keto-carbonyl to hydroxyl group at C-8 may enhance the anti-HIV activity of these compounds.

Table 2. Anti-HIV activities of the 7,8-secolignans

\begin{tabular}{lccc}
\hline Compound & $\mathrm{CC}_{50} /\left(\mu \mathrm{gL}^{-1}\right)$ & $\mathrm{EC}_{50} /\left(\mu \mathrm{g} \mathrm{mL}^{-1}\right)$ & $\mathrm{TI}$ \\
\hline $\mathbf{1}$ & 186.5 & 3.18 & 58.65 \\
$\mathbf{2}$ & 111.3 & 4.22 & 26.36 \\
$\mathbf{3}$ & 91.8 & 3.87 & 23.71 \\
$\mathbf{4}$ & 107.0 & 4.14 & 25.85 \\
$\mathrm{AZT}$ & $>200$ & 0.029 & $>6896.55$ \\
\hline
\end{tabular}

$\mathrm{CC}_{50}$ : median cytotoxic concentration; $\mathrm{EC}_{50}$ : concentration for $50 \%$ of maximal effect; TI: $\mathrm{CC}_{50} / \mathrm{EC}_{50}$

\section{Experimental}

\section{General experimental procedures}

Optical rotations were measured with a Horiba SEPA-300 polarimeter. UV spectra were obtained using a Shimadzu UV-2401A spectrophotometer. A Tenor 27 spectrophotometer was used for scanning IR spectroscopy with $\mathrm{KBr}$ pellets. 1D and 2D NMR spectra were recorded on DRX-500 spectrometers with TMS (tetramethylsilane) as internal standard. Unless otherwise specified, chemical shifts $(\delta)$ were expressed in ppm with reference to the solvent signals. HRESIMS was performed on an API QSTAR time-of-flight spectrometer and a VG Autospec-3000 spectrometer, respectively. Preparative HPLC was performed on a Shimadzu LC-8A preparative liquid chromatograph with a ZORBAX PrepHT GF $(21.2 \mathrm{~mm} \times 25 \mathrm{~cm}, 7 \mu \mathrm{m})$ column or a Venusil MP $\mathrm{C}_{18}$ $(20 \mathrm{~mm} \times 25 \mathrm{~cm}, 5 \mu \mathrm{m})$ column. Column chromatography was performed with silica gel (200-300 mesh, Qing-dao Marine Chemical, Inc., Qingdao, China), Lichroprep RP-18 gel (40-63 $\mu \mathrm{m}$, Merck, Darmstadt, Germany) and MCI gel (75-150 $\mu \mathrm{m}$, Mitsubishi Chemical Corporation, Tokyo, Japan). The fractions were monitored by TLC (thin layer chromatography), and spots were visualized by heating $\mathrm{Si}$ gel plates sprayed with $5 \% \mathrm{H}_{2} \mathrm{SO}_{4}$ in $\mathrm{EtOH}$.

\section{Plant material}

The leaves and stems of S. neglecta were collected in on Lijiang Country, Yunnan Province, People's Republic 
of China, in September 2009. The identification of the plant material was verified by Prof. Xi-Wen Li of Kunming Institute of Botany, Chinese Academy of Sciences. A voucher specimen (KIB 09-9-34) was deposited in the State Key Laboratory of Phytochemistry and Plant Resources in West China, Kunming Institute of Botany, Chinese Academy of Sciences.

\section{Extraction and isolation}

The air-dried and powdered leaves and stems of S. neglecta $(4.0 \mathrm{~kg})$ were extracted four times with $70 \%$ aqueous $\mathrm{Me}_{2} \mathrm{CO}(4 \times 5 \mathrm{~L})$ at room temperature and filtered, with the filtrate evaporated under reduced pressure and partitioned with EtOAc $(4 \times 5 \mathrm{~L})$. The EtOAc partition (212 g) was applied to silica gel (200-300 mesh) column chromatography, eluting with a $\mathrm{CHCl}_{3}-\mathrm{MeOH}$ gradient system (20:1, 9:1, 8:2, 7:3, 6:4, 5:5), to give six fractions A-F. The further separation of fraction $\mathrm{B}(9: 1,52.5 \mathrm{~g})$ by silica gel column chromatography, eluted with $\mathrm{CHCl}_{3}$ :acetone (20:1-2:1), yielded mixtures A1-A7. Fraction A2 (9:1, $36 \mathrm{~g}$ ) was subjected to silica gel column chromatography using petroleum ether-acetone and semi-preparative HPLC $\left(65 \% \mathrm{MeOH}-\mathrm{H}_{2} \mathrm{O}\right.$, flow rate $\left.12 \mathrm{~mL} \mathrm{~min}^{-1}\right)$ to give $5(17.2 \mathrm{mg})$ and 6 (21.4 mg). Fraction A3 (8:2, $15.8 \mathrm{~g})$ was subjected to silica gel column chromatography using petroleum ether-acetone and semi-preparative HPLC $(60 \%$ $\mathrm{MeOH}-\mathrm{H}_{2} \mathrm{O}$, flow rate $\left.12 \mathrm{~mL} \mathrm{~min}{ }^{-1}\right)$ to give $\mathbf{1}(16.4 \mathrm{mg})$, 2 (8.64 mg), 3 (10.6 mg) and 4 (8.25 mg).

\section{Anti-HIV-1 assay}

The cytotoxicity assay against $\mathrm{C} 8166$ cells $\left(\mathrm{CC}_{50}\right.$, concentration for $50 \%$ of maximal effect) was assessed using the MTT method and anti-HIV-1 activity was evaluated by the inhibition assay for the cytopathic effects of HIV-1 $\left(\mathrm{EC}_{50}\right){ }^{10}$

\section{Neglectahenol A (1)}

White amorphous powder; $[\alpha]_{\mathrm{D}}^{26.5}+22.6(c \quad 0.22$, $\mathrm{MeOH}) ; \mathrm{UV}(\mathrm{MeOH}) \lambda_{\max } / \mathrm{nm}(\log \varepsilon): 210$ (4.26), 276 (3.88), 340 (2.78); IR (KBr) $v_{\text {max }} / \mathrm{cm}^{-1} 3475,3065,2938$, 2854, 1708, 1658, 1574, 1523, 1475, 1392, 1345, 1258, $1135,1027,982,876 ;{ }^{1} \mathrm{H}$ NMR (500 MHz, $\left.\mathrm{C}_{5} \mathrm{D}_{5} \mathrm{~N}\right) \delta 7.59$ $(1 \mathrm{H}, \mathrm{d}, J 1.8 \mathrm{~Hz}, \mathrm{H} 2), 6.87(1 \mathrm{H}, \mathrm{d}, J 8.2 \mathrm{~Hz}, \mathrm{H} 5), 7.85$ $(1 \mathrm{H}, \mathrm{dd}, J 1.8,8.2 \mathrm{~Hz}, \mathrm{H} 6), 4.63$ (1H, m, H8), 1.41 (3H, d, $J 6.4 \mathrm{~Hz}, \mathrm{H} 9), 6.91(1 \mathrm{H}, \mathrm{s}, \mathrm{H} 2 '), 7.27\left(1 \mathrm{H}, \mathrm{s}, \mathrm{H} 6^{\prime}\right), 6.40(1 \mathrm{H}$, d, J $\left.10.3 \mathrm{~Hz}, \mathrm{H} 77^{\prime}\right), 2.36$ (1H, m, H8'), 1.05 (3H, d, J $6.6 \mathrm{~Hz}$, H9'), 3.82 (3H, s, MeO-3'), 3.75 (3H, s, MeO-4'), 5.99, 6.01 $\left(2 \mathrm{H}, \mathrm{s},-\mathrm{OCH}_{2} \mathrm{O}-\right) ;{ }^{13} \mathrm{C}$ NMR data, Table 1 ; positive ESIMS $m / z 427[\mathrm{M}+\mathrm{Na}]^{+} ;$HRESIMS $m / z 427.1372[\mathrm{M}+\mathrm{Na}]^{+}$, (calcd. $\mathrm{C}_{21} \mathrm{H}_{24} \mathrm{NaO}_{8}$ for 427.1369).

\section{Neglectahenol B (2)}

White amorphous powder; $[\alpha]_{\mathrm{D}}^{26.5}+18.4$ (c 0.20 , $\mathrm{MeOH}) ; \mathrm{UV}(\mathrm{MeOH}) \lambda_{\max } / \mathrm{nm}(\log \varepsilon) 210$ (4.19), 275 (3.86), 340 (2.82); IR (KBr) $v_{\max } / \mathrm{cm}^{-1} 3482,3047,2932$, 2875, 1712, 1655, 1577, 1526, 1474, 1397, 1344, 1261, $1130,1024,987,874 ;{ }^{1} \mathrm{H}$ NMR $\left(500 \mathrm{MHz}, \mathrm{C}_{5} \mathrm{D}_{5} \mathrm{~N}\right) \delta 7.78$ $(1 \mathrm{H}, \mathrm{d}, J 1.8 \mathrm{~Hz}, \mathrm{H} 2), 6.89(1 \mathrm{H}, \mathrm{d}, J 8.1 \mathrm{~Hz}, \mathrm{H} 5), 7.89$ $(1 \mathrm{H}, \mathrm{dd}, J 1.8,8.2 \mathrm{~Hz}, \mathrm{H} 6), 4.64(1 \mathrm{H}, \mathrm{m}, \mathrm{H} 8), 1.42(3 \mathrm{H}$, d, J $6.4 \mathrm{~Hz}, \mathrm{H} 9), 7.35(1 \mathrm{H}, \mathrm{d}, J 1.8 \mathrm{~Hz}, \mathrm{H} 2$ '), $7.11(1 \mathrm{H}, \mathrm{d}$, $J 8.1 \mathrm{~Hz}, \mathrm{H} 5 '), 7.25$ (1H, dd, J 1.8, 8.1 Hz, H6'), $6.37(1 \mathrm{H}$, d, J $\left.10.4 \mathrm{~Hz}, \mathrm{H} 7{ }^{\prime}\right), 2.37$ (1H, m, H8'), $1.01(3 \mathrm{H}, \mathrm{d}, J 6.8 \mathrm{~Hz}$, $\left.\mathrm{H}^{\prime}\right), 3.88$ (3H, s, MeO-3'), 5.94, 5.96 (2H, s, $\left.-\mathrm{OCH}_{2} \mathrm{O}-\right)$, $11.01(1 \mathrm{H}, \mathrm{s}, \mathrm{Ar}-\mathrm{H}) ;{ }^{13} \mathrm{C}$ NMR data, Table 1; positive ESIMS $m / z 397[\mathrm{M}+\mathrm{Na}]^{+} ;$HRESIMS $m / z 397.1270$ $[\mathrm{M}+\mathrm{Na}]^{+}$(calcd. $\mathrm{C}_{20} \mathrm{H}_{22} \mathrm{NaO}_{7}$ for 397.1263).

\section{Neglectahenol C (3)}

White amorphous powder; $[\alpha]_{\mathrm{D}}^{26.5}+18.9$ ( c 0.21 , $\mathrm{MeOH}) ; \mathrm{UV}(\mathrm{MeOH}) \lambda_{\max } / \mathrm{nm}(\log \varepsilon): 210$ (4.21), 275 (3.93), 340 (2.76); IR (KBr) $v_{\text {max }} / \mathrm{cm}^{-1} 3486,3042,2935$, 2871, 1716, 1653, 1579, 1554, 1525, 1470, 1394, 1345, 1266, 1134, 1058, 1020, 980, 877; ' ${ }^{\mathrm{H}} \mathrm{NMR}(500 \mathrm{MHz}$, $\left.\mathrm{C}_{5} \mathrm{D}_{5} \mathrm{~N}\right) \delta 7.44(1 \mathrm{H}, \mathrm{d}, J 1.8 \mathrm{~Hz}, \mathrm{H} 2), 7.04(1 \mathrm{H}, \mathrm{d}, J 8.2 \mathrm{~Hz}$, H5), 7.66 (1H, dd, J 1.8, 8.2 Hz, H6), 4.47 (1H, m, H8), 1.33 (3H, d, J 6.4 Hz, H9), 6.48 (2H, s, H-2', H6'), 5.33 $\left(1 \mathrm{H}, \mathrm{d}, J 10.3 \mathrm{~Hz}, \mathrm{H} 77^{\prime}\right), 2.55\left(1 \mathrm{H}, \mathrm{m}, \mathrm{H} 8^{\prime}\right), 1.06(3 \mathrm{H}, \mathrm{d}$, $J 6.8 \mathrm{~Hz}, \mathrm{H} 9 '), 3.68$ (3H, s, MeO-3), 3.80 (3H, s, MeO-4), 3.87 (3H, s, MeO-3'), 3.80 (3H, s, MeO-4'), 3.90 (3H, s, $\mathrm{MeO}-5$ '),; ${ }^{13} \mathrm{C}$ NMR data, Table 1; positive ESIMS $m / z 457$ $[\mathrm{M}+\mathrm{Na}]^{+}$; HRESIMS m/z $457.1832[\mathrm{M}+\mathrm{Na}]^{+}$, (calcd. $\mathrm{C}_{23} \mathrm{H}_{30} \mathrm{NaO}_{8}$ for 457.1838).

\section{Neglectahenol D (4)}

White amorphous powder; $[\alpha]_{\mathrm{D}}^{26.5}+16.9$ (c 0.20 , $\mathrm{MeOH}) ; \mathrm{UV}(\mathrm{MeOH}) \lambda_{\max } / \mathrm{nm}(\log \varepsilon): 210$ (4.15), 275 (3.87), 340 (2.69); IR (KBr) $v_{\text {max }} / \mathrm{cm}^{-1} 3483,3039,2930$, 2874, 1713, 1656, 1575, 1551, 1526, 1467, 1398, 1351, 1269, 1137, 1038, 1027, 979, 872; ${ }^{1} \mathrm{H}$ NMR $(500 \mathrm{MHz}$, $\left.\mathrm{C}_{5} \mathrm{D}_{5} \mathrm{~N}\right) \delta 7.49(1 \mathrm{H}, \mathrm{d}, J 1.8 \mathrm{~Hz}, \mathrm{H} 2), 7.02(1 \mathrm{H}, \mathrm{d}, J 8.2 \mathrm{~Hz}$, H5), 7.67 (1H, dd, J 1.8, $8.2 \mathrm{~Hz}, \mathrm{H} 6), 4.63(1 \mathrm{H}, \mathrm{m}, \mathrm{H} 8)$, 1.42 (3H, d, J 6.4 Hz, H9), 6.89 (1H, s, H2'), 7.30, (1H, s, H6'), 6.37 (1H, d, J 10.3 Hz, H7'), 2.36 (1H, m, H8'), 1.03 $\left(3 \mathrm{H}, \mathrm{d}, J 6.8 \mathrm{~Hz}, \mathrm{H}^{\prime}\right), 3.81$ (3H, s, MeO-3), $3.86(3 \mathrm{H}, \mathrm{s}$, MeO-4), 3.96 (3H, s, MeO-3'), 3.85 (3H, s, MeO-4'), 11.10 (1H, brs, Ar-OH); ${ }^{13} \mathrm{C}$ NMR data, Table 1; positive ESIMS 
$m / z, 443[\mathrm{M}+\mathrm{Na}]^{+} ;$HRESIMS $m / z 443.1675[\mathrm{M}+\mathrm{Na}]^{+}$, (calcd. $\mathrm{C}_{22} \mathrm{H}_{28} \mathrm{NaO}_{8}$ for 443.1682).

\section{Supplementary Information}

${ }^{13} \mathrm{C}$ and ${ }^{1} \mathrm{H}$ NMR and DEPT spectra of neglectahenols A-D and HSQC, HMBC, ${ }^{1} \mathrm{H}-{ }^{1} \mathrm{H}$ COSY, ROESY and HRESIMS spectra of neglectahenol A are available free of charge at http://jbcs.sbq.org.br as PDF file.

\section{Acknowledgments}

This project was financially supported by the NSFC (30830115) and the project from the Chinese Academy of Sciences (KSCX2-EW-Q-10).

\section{References}

1. Saunders, R. M. K.; Syst. Bot. Monogr. 2000, 58, 1.

2. Yao, D.M.; Zhang, J. B.; A Coloured Atlas of the Chinese Materia Medica Specified in Pharmacopoeia of the People's
Republic of China; Guangdong Science \& Technology Press: Guangdong, China, 1995 ed., p. 78.

3. Chang, J. B.; Reiner, J.; Xie J. X.; Chem. Rev. 2005, 105, 4581.

4. Xiao, W. L.; Li, R. T.; Huang, S. X.; Pu, J. X.; Sun, H. D.; Nat. Prod. Rep. 2008, 25, 871.

5. Chen, M.; Xu, X. M.; Liao, Z. H.; Dong, L.; Li, L.; Huang, C. Z.; Molecules 2008, 13, 548.

6. Chen, M.; Liao, Z. Z.; Xu, X. M.; Wen, Y.; Sun, M.; Zhang, H. X.; Ma, W. X.; Molecules 2008, 13, 1148.

7. Duan, Y. X.; Cao, J. L.; Wen, R. R.; Yang, G. Y.; Pu, J. X.; Sun, H. D.; Xiao, W. L.; Li, G. P.; J. Asian Nat. Prod. Res. 2011, 13, 592.

8. Zhang, X. J.; Yang, G. Y.; Wang, R. R.; Pu, J. X.; Sun, H. D.; Xiao, W. L.; Zheng, Y. T.; Chem. Biodivers. 2010, 7, 2692.

9. da Silva, T.; Lopes, L. M. X.; Phytochem. 2004, 65, 751.

10. Wang, J. H.; Tam, S. C.; Huang, H.; Ouyang, D. Y.; Wang, Y. Y.; Zheng, Y. T.; Biochem. Biophys. Res. Commun. 2004, 317, 965.

Submitted: February 2, 2012 Published online: October 11, 2012 